\title{
Histone H2B Type 1-L
}

National Cancer Institute

\section{Source}

National Cancer Institute. Histone H2B Type 1-L. NCI Thesaurus. Code C162952.

Histone H2B type 1-L (126 aa, $14 \mathrm{kDa}$ ) is encoded by the human H2BC13 gene. This protein is involved in nucleosome stabilization. 